\title{
Is the legislation important in the context of transfer pricing?
}

\author{
Katarina Zvarikova ${ }^{1, *}$, and Erika Kovalova ${ }^{1}$ \\ ${ }^{1}$ University of Zilina, Faculty of Operation and Economics of Transport and Communication, \\ Department of Economics, Univerzitna 8215/1, 01026 Zilina, Slovak Republic
}

\begin{abstract}
.
Research background: The continuing trend of globalization and interconnection of national economics is reviling many opportunities as well as threats arising from this development. The transfer pricing is one of these issues as a legal framework to adjust the tax base. But on the other hand, this issue also affects other important areas and reveals its risks. There is focused on the transfer pricing and its legal framework in these presented papers as recent years have indicated that there is a huge necessity to regulate and legislatively define the transfer pricing on the part of the state. And although we can take the opinion that this is a modern issue, we have been encountering this problem since 1915 and since this time it is gaining in its importance.

Purpose of the article: We can distinguish two different parties. On the one hand, there is a company (most of the time its multinational company) with its goal to achieve the best possible efficiency also by paying the lowest possible taxes. On the other hand, we recognize the state with his aim of optimal tax policy allowing it to maximize the amount of collected taxes, i. e. it should be in the best interest of the state to define the transfer pricing precisely to prevent possible tax evasion.

Methods: The main method used in the article is literature research and analysis of the law documents.

Findings \& Value added: The aim of this article is to identify the basic legislative guidelines in the field of transfer pricing in the international level as well as in the level of the Slovak republic.
\end{abstract}

Keywords: transfer pricing, tax, company, the Slovak republic

JEL Classification: $E 62, G 38, K 34$

${ }^{*}$ Corresponding author : katarina.zvarikova@,fpedas.uniza.sk 


\section{Introduction}

With the growing worldwide trend of globalization and interconnection of world economies, the concept of transfer pricing is getting to forefront, mainly due to the significant tax differences between individual countries, which thus creates environment for tax optimization. In connection with the efforts of multinational companies to reduce taxes, the issue of transfer pricing has become a top priority for the OECD and G8 members. [1] Pendse [2] states that there is amount of publications tackling with international transfer pricing mainly as the tool for tax minimization and international tax management.

A lot of big companies operate in different international markets at the same time, and transactions in their close relationships should be traded at standard prices and standard market conditions, but this presumption is often unkept [3]. Thus, the issue of transfer prices has become an interdisciplinary topic, which intervenes mainly in tax, commercial, criminal or international law, but at the same time it is also able to affect the risk management or financial management of the corporate. Already S. Shulman [4] in his work defined the rising necessity to set transfer prices also from the point of view of various "non-tax" reasons. ${ }^{\dagger}$ Also, Pendse [2] argues that in many cases taxes are not a priority for transfer pricing

But on the other hand, there is much more publications in which the transaction prices are associated with the tax burden, respectively the transaction prices as a space for legal adjustment of the tax base $[3,5]$. So we can consider two conflicting interests which come into confrontation. On the one hand, there is a state with its goal of an optimal tax policy that will allow to it to maximize the amount of collected taxes. On the other hand, there is a corporate, which goal is the highest possible efficiency and thus e.g. also a reduction in the tax base. But necessarily, there is no need to always look for criminal intent behind the corporate practices. The disagreement between these two parties is often due to conflicting interests and different views on the same issue. ${ }^{\star}$ However, many experienced managers are able to achieve low taxation due to their knowledge of different tax systems, while still being within the law. [1] These practises causing an arousing interest of tax administrations at national levels in order to minimize them. But most of the corporates financial reports rarely provide relevant information about transfer pricing practices. [3, 7] The aim is therefore to create the procedures that will accept and respect the arm's length principle.

If we need to define transfer prices, we consider them as the prices agreed for services or goods between two or more associated parties. ${ }^{\S}$ Associated parties (enterprises) represent property-related or personnel-related entities, and it is therefore clear that the conditions of transaction prices' determination will be realized under different conditions than between unrelated entities. Cristea [1] argues that without regulation, connected persons would not always act as independent persons, because the main motive of related persons is to achieve better results than they would be able to achieve independently. Thus, the specificity of transactions carried out between associated parties lies mainly in the possibility of using transaction prices to influence, resp. reduction of the tax base. However, we must not forget that transfer prices have a significant impact not only at the international level, but also at

\footnotetext{
$\dagger$ In his study Shulman presents the impact of the transfer pricing in the context of price rate, economics restrictions, competitive positon, political instability or interpersonal relationships.

$¥$ At this point, we would like to emphasize that although in the publications tackling with this issue the transfer pracing is mentioned mainly with multinational corporations in the context of globalization, it may also affect companies at the national level. [6] However, more possibilities for adjusting the tax base is given to companies doing business in several national markets (different tax jurisdictions) at the same time.

$\S$ Unrelated parties are managed by the principle of maximizing benefits (e.g. profit), which does not necessarily have to be respected for associated persons.
} 
the national level, even though their international reach has created them as a global issue. This is the basis for the principle of arm's length principle, which should be applied in the context of transfer pricing. However, it is not always possible to comply with it, as there are often transactions between related parties that would not be realized between unrelated parties. On the contrary, it is very rare for related parties to trade a product which there is a perfectly competitive market for.

Deducing from the previous text we are able to claim that, despite the fact that transfer prices are in the focus of manager (so it is managerial issue) but in most cases we consider them as a tool to optimize the company's tax expenditures in order to prevent repression caused by their incorrect, respectively not completely transparent way of application. We need to be aware that it is not the matter of the tax audit to prove incorrect setting of transfer prices, but it is the matter of the taxable person to prove that the transaction prices were not set in order to intentionally reduce the tax liability. So the tax's burden of proof is on the side of taxable person not on the side of tax officers.

\section{Methods}

From the previous text, it is obvious that the regulation of international transfer pricing legislation is necessary, because if it were absent, multinational companies would basically just choose the country most suitable for paying taxes and shifting their profits to it [8]. Therefore, it is necessary to perceive the legislative regulation not only at the national level but also in the context of international regulation. However, it is not always clear that the aim of the intentional use of transfer pricing is to reduce tax liability. [9] In the literature we can also observe tendencies to eliminate tax differences in the global environment in order to test the tendency of multinational companies to shift income to low tax jurisdictions. $[10]^{* *}$ Increasing importance of the transfer pricing issue is also supported by the fact that in many countries more and more tax controls have being carried out focusing on this specific field. As an illustration, we demonstrate the situation in the Slovak Republic, which is shown in the following table (Table 1).

Tab. 1 Number of tax controls in the Slovak republic ${ }^{\dagger \dagger}$

\begin{tabular}{|l|c|c|c|c|c|c|c|c|}
\hline Year & 2012 & 2013 & 2014 & 2015 & 2016 & 2017 & 2019 & 2020 \\
\hline $\begin{array}{l}\text { number of } \\
\text { controls } \\
\text { value }\end{array}$ & 18 & 10 & 21 & 32 & 59 & 144 & 32 & 27 \\
\cline { 2 - 9 } & 1997 & 334 & 21473 & 12056 & $\mathbf{8 1 8 7}$ & 51152 & 51210 & 171019 \\
\hline
\end{tabular}

[11]

Each legal person filing a tax declaration must state in it whether it carried out transactions with associated companies, but the financial administration does not statistically process this information. It is estimated that this obligation applies to around $12 \%$ of legal persons, representing around 30000 entities. In 2019, approximately every second inspection were ended with the imposition of a tax. [12] If the tax administrators were able to perform tax audits it is necessary to create a relevant legal framework. Therefore it is appropriate to state the basic legislative regulations of transfer pricing in the Slovak Republic, while we must not forget to take into account the international legislation,

\footnotetext{
** Some of the publications urges nation-states to eliminate tax differentials in the hope that this would check the multinational companies' tendency to shift profits to low-tax jurisdictions

it Statistics of Financial Administration summarizes transfer pricing controls and double taxation avoidance controls in one number. But in 2017 these controls also included additional network controls and multilateral controls. These fact caused the significant increase of controls in this year.
} 
which is not obligatory for the Slovak Republic but provides recommendations in the field of transfer prices.

For the purposes of this paper, standard scientific methods such as excerpt, abstraction, analysis, synthesis, induction and deduction were used, working with secondary data sources including available literature sources and legal regulations.

\section{Results}

\subsection{International legislation}

Previous information may evoke the belief that the issue of transfer pricing is only a topic of the near past. But this issue many authors and legislators has been tackle with for longer time. Already in 1908 there was a lawsuit in the UK, where the tax administrator lost and so in order to prevent the emergence of a dangerous precedent there were introduced "Finance act" in 1915, which aim was to prevent a negative impact on the country's tax revenues. Further attempts to regulate transfer prices are dated back to the 1950s and 1960s especially in the UK and in the USA. OECD document is considered as one of the first comprehensive set of rules in the field of transfer pricing. But for example, Stuart [14] claims that these Guidelines for transfer prices include a high degree of subjectivity.

In 1979, the document Transfer Pricing and Multinational Enterprises was published, but it was not officially issued and approved by the OECD Committee for Fiscal Affairs until 1995 as Pricing Guidelines for Multinational Enterprises and Tax Administrations (hereinafter referred to as Pricing Guidelines). Over the years, there were several updates, the last was made in 2017. The mentioned last edit consist of 9 specific chapters, which deal with e.g. arm's length principle, define methods for transfer pricing, comparative analysis, approaches in tax administration, how to avoid disputes in the field of transfer pricing, documentation and other important problems related to the issue. [15] Although Pricing Guideless is not a legal regulation, for OECD member countries it represents a recognized methodological document (i.e. it also applies to the Slovak Republic).

Another document, which is focused on tax base erosion and profit shifting, is Base Erosion and Profit Shifting (BEPS), which was agreed by representatives of the world's 20 largest economies (G20). BEPS represents a tax technique that uses tax gaps in different states (with different tax jurisdictions), which is used to transfer profits to more tax-friendly areas. According to the OECD analysis, as a result of BEPS, the accumulated collection of income taxes of legal persons worldwide is $4-10 \%$ lower than it should be, which is in absolute amounts 100-240 billion dollars. [16] Therefore, the G20 countries decided to ask the OECD to develop an action plan to reduce BEPS. In 2015, the OECD published 15 action plans, which have become instruments used in the fight against BEPS, and by February 2020, they have been implemented by a total of 137 countries. [16]

Another equally important OECD document is the Model Tax Convention on Income and on Capital (hereinafter referred to as the Model Tax Convention), which was established in 1977 and has been updated several times (last update 2017). This Model Tax Convention is considered as a model treatment according to which it is able to conclude bilateral income tax treaties between two states. Under this treaty, most double taxation treaties are concluded between OECD member countries as well as between non-members. From the point of view of transfer pricing issues, the most important article in the Model Tax Convention is Article 9, which defines related parties and also regulates how to adjust the tax base to a business by the difference between the profit from the transaction between 
associated parties and the profit that would be achieved between independent companies (as a basis of the arm's length principle). [17]

EU member states follow the OECD Guidelines, but due to the fact that each member state has different legislation governing this issue, the EU institutions decided to harmonize the issue of transfer pricing. The EU Joint Transfer Pricing Forum was established in 2002. The one of its the most important publication is the Code of conduct for the effective implementation of the Convention on the elimination of double taxation in connection with the adjustment of profits of associated enterprises. It is basically an interpretation of the more important document Convention on the elimination of double taxation in connection with the adjustment of profits of associated enterprises. It deals with cases where the administrator of one state considers the price for the received performance to be too high and therefore non-deductible for tax purposes. But on the other hand, it means that taxpayer in another state taxed inadequate amount of sales in his domestic state. The second document is the Code of conduct on transfer pricing documentation for associated enterprises in the European Union, which aim is to unify the requirements for documentation required for transfer pricing. [18]

We consider as necessary to emphasize in this point that, although these guidelines are a key harmonization tool for regulating the fight against tax avoiding linked to transfer pricing, they do not in themselves represent a source of law and it follows that it is absolutely in the competence of the states in which way they incorporate them into their legal framework. The experiences show that countries apply different approaches to the implementation and interpretation of principles, and thus different instruments to prevent unjustified reductions in tax bases and, if the situation requires, also different repressive interventions are applied.

\subsection{Legislative framework of transfer pricing in the conditions of the Slovak republic}

Even in the conditions of the Slovak Republic, the pressure on the companies' tax control is constantly increasing, focusing mainly on the field of transfer prices and thus also on the detail of controls, while the most critical areas are considered to be e.g. management and licensing fees, financial transactions and companies at a loss. The Financial Administration has dedicated specialized auditors to this issue, and according to its statement is observed a change in the development of tax compliance. The Financial Administration increases activity in this field by higher amount of inspections, which are performed at a higher professional level, which also has a positive effect on promoting voluntary compliance and increasing tax obligations of entities. These steps also assume a preventive effect, elimination of tax evasion and consequently higher revenues to the national budget. [11]

Law and solution of transfer pricing issues are based on the OECD Guidelines and the Code of Conduct in the field of transfer pricing documentation. And although, as it was mentioned above, the OECD principles are not directly followed by the Slovak law, the binding nature of the guidelines' interpretation follows from the fact that the Slovak Republic is a signatory to them.

Significant attention to the issue of transfer prices was given by the Act No. 595/2003 Coll. on the Income Tax as amendment, from 2015, which amplified the issue from the level of international corporations also to domestic related parties. Section 2 (n) of the Act No. 595/2003 declares that if associated parties make controlled transactions between them, the prices have to be set at the level of arm's length principle. [19]

\# In comparable transactions and circumstances. 
Since 2001, the Income Tax Act has specified in detail the specific methods of arm's length principle, according to which tax subjects adjust their internal company transactions in accordance with the arm's length principle. The obligation to manage documentation according used method has been established in law since 2009 .

The Slovak legal system seems to be more casuistic, it defines associated persons according to specific criteria and not according to general principles. Regardless of whether it is an entrepreneur - self-employed person or a legal entity, the definition of a related person is regulated directly by Act no. 595/2003 Coll. on the Income Tax. For the purposes of transfer pricing, a related person is defined by law as: a close person, economically and personally or otherwise connected person or entity, person or entity that is a part of the consolidated unit on behalf of the consolidation account.

Related person is determined in the conditions of the Slovak republic by the Civil Code as a relative in the direct line, a sibling, spouse but also other persons in a family or similar relationship are considered to be close to each other if the damage suffered by one of them was reasonably felt by the other as their own damage. [20]

Economic or personnel interconnection under the Income Tax Act means the participation of a person in the property, control or management of another person or the relationship between persons under the control or management of the same person, the law providing a fairly exhaustive definition of economic and personnel interconnection, minimal by $25 \%$ of the share capital, voting rights or profit. $\$ \S$ When defining relative persons, it is necessary to mention section 2 (b) which defines the controlled transaction as a legal relationship or other similar relationship between two or more dependents persons.

Another important legal regulation of transfer pricing concerns to Country-by-country reporting and is established in the amendment to Act no. 442/2012 Coll on International Assistance and Cooperation in Tax Administration, which, with validity from 1 March 2017, introduces a new obligation, in particular the primary obligation ${ }^{* * *}$ and the notification obligation for associated persons meeting the criteria set by law. [21]

Within the scope of the transfer pricing issue, guidelines and methodological guidelines are also used in the conditions of the Slovak Republic, which are focused on the documentation of transfer prices and on the selection and use of relevant methods for their determination. Specifically, these are:

- Guideline of the Ministry of Finance of the Slovak Republic no. MF / 014283 / 2018-724 presents details on content of the documentation on the pricing method under the Section 18 (1) of Act No. 595/2003 Coll. On the Income Tax as amended. Guideline was updated 4 times and the last update was in 2018 and it significantly affected the scope of the documentation obligation as well as the content of the documentation. [22]

- methodological instruction on the application of transfer pricing methods, the aim of which is to approximate the fundamentals of individual methods.

The documentation is compiled in order to document the process of valuing mutual transactions, the relationship and transactions of the taxpayer, including prices for services provided loans and other information that affect the valuation of these transactions. The obligation to keep documentation is established in the Income Tax Act Section 18.

\footnotetext{
$\S \S$ Since 2018 , it is sufficient if the profit share is at least $25 \%$ in the capital and voting rights only $10 \%$.

*** Primary obligation represents an obligation for tax entities to inform the Slovak financial administration about their position in the group as well as about details of the entity that the Countryby-Country statement reports in behalf of the group
} 


\section{Discussion and conclusion}

The transfer pricing is becoming a topical issue not only globally, but also in the conditions of the Slovak Republic, where more and more international companies are starting to operate. However, we must not forget that this issue concerns not only multinational corporations, but also companies that operate at national level and meet the conditions of related companies [23]. However, it should be emphasized that no law explicitly forbit entrepreneurs from setting prices with related entities above or below market values. But their behaviour has tax implications specifically in the Income Tax Act, which subsequently requires to adjust the tax base so that the resulting discrepancy is corrected. In the case of a difference between prices and conditions in the case of transactions with related persons in comparison with un-related persons, if this difference reduces the tax base or increases the tax loss, they must, according to Section 17 (5) of the Income Tax Act, adjust the tax base in the amount of the difference.

However, we must not forget that companies that successfully use transfer pricing for tax minimization often have experienced staff, very well-equipped tax departments and resources focused on tax planning [24] and therefore it is often very difficult for the financial administration to detect the intention to reduce the tax base.

On the other hand, it is also very important to detect another effects of transfer pricing, because most of the papers are focused only on the tax side of transfer pricing. But there are another effects of transfer pricing which need to be researched.

The paper is an output of the science project VEGA 1/0121/20: Research of transfer pricing system as a tool to measure the performance of national and multinational companies in the context of earnings management in conditions of the Slovak Republic and V4 countries

\section{References}

1. Cristea, A. D., Nguyen, D. X. (2016). Transfer Pricing by Multinational Firms: New Evidence from Foreign Firm Ownership. American Economic Journal: Economic Policy, 8(3), 170-202.

2. Pendse, S. J. (2012). International Transfer Pricing: A Review of Non-Tax Outlook. In: Patil, Y.B. (Eds.), International Conference on Emerging Economies - Prospects and Challenges (ICEE (pp. 337-343). India: Procedia - Social and Behavioral Sciences.

3. Swenson, D. (2001). Tax Reforms and Evidence of Transfer Pricing. National Tax Journal, 54(1), 7-25.

4. Shulman, J. (1968). Transfer pricing in the multinational firm. Massachusetts institute of technology, 7-8.

5. Bartelsmana, E. J., Beetsma, M. W. J. (2003). Why pay more? Corporate tax avoidance through transfer pricing in OECD countries. Journal of Public Economics Volume, 87(9-10), 2225-2252.

6. Nemec, J. (2003). Business environment - The problem of economic conditions or institutional system difficulty? Ekonomicky casopis, 51(2), 137-167

7. Tang, R. Y. W., Zhao, J. (2001). A look at the segment reporting practices of some Fortune 500 companies. Journal of Corporate Accounting \& Finance, 10(3), 127-43.

8. Al-Eryani, M., Alam, P., Akhter, S. (1990). Transfer Pricing Determinants of U.S. Multinationals. Journal of International Business Studies, 21, 409-425.

9. Sikkaa, P., Willmottb, H. (2010). The dark side of transfer pricing: Its role in tax avoidance and wealthretentiveness. Critical Perspectives on Accounting, 21, 342-356.

10. Borkowski, S. C. (1997). The transfer pricing concerns of developed and developing countries. The International Journal of Accounting, 32(3), 321-36. 
11. Financna sprava. Annual reports of the Financial Administration of the Slovak republic. Retrieved from: https://www.financnasprava.sk/sk/financna-sprava/vyrocnespravy

12. Senesi, N. (2020, August 20). Kontrola transferoveho ocenovania na Slovensku. Retrieved from: https://www.podnikajte.sk/dan-z-prijmov/kontrola-transferovehoocenovania-na-slovensku

13. Henshall, J. (2016). Global transfer pricing: principles and practice. Third edition. Haywards Heath: Bloomsbury Professional.

14. Stuart, A. (2009). Transfer Pricing: A World of Pain. Retrieved from: https://www.cfo.com/accounting-tax/2009/09/transfer-pricing-a-world-of-pain/

15. OECD (2020). OECD Pricing Guidelines for Multinational Enterprises and Tax Administrations 2017. Retrieved from: https://read.oecd-ilibrary.org/taxation/oecdtransfer-pricing-guidelines-for-multinational-enterprises-and-tax-administrations2017 tpg-2017-en\#page4

16. OECD (2015). Explanatory Statement, OECD/G20 Base Erosion and Profit Shifting Project. Retrieved from: www.oecd.org/tax/beps-explanatory-statement-2015.pdf

17. OECD (2019). Model Tax Convention on Income and on Capital (Full version). Retrieved from: https://read.oecd-ilibrary.org/taxation/model-tax-convention-onincome-and-on-capital-2017-full-version_g2g972ee-en\#page3

18. European Committee (2005). Code of conduct on transfer pricing documentation for associated enterprises in the European Union. Retrieved from: https://ec.europa.eu/commission/presscorner/detail/en/MEMO $05 \quad 414$

19. National Council of the Slovak republic (2014). Act No. 595/2003 Coll. on the Income Tax as amendment. Retrieved from: https://www.slov-lex.sk/pravnepredpisy/SK/ZZ/2003/595/

20. National Council of the Slovak republic (2010). Act No. 40/1964 Civil Code as amendment. Retrieved from: https://www.slov-lex.sk/pravnepredpisy/SK/ZZ/1964/40/20191201

21. National Council of the Slovak republic (2020). Act no. 442/2012 Coll on International Assistance and Cooperation in Tax Administration. Retrieved from: https://www.slovlex.sk/pravne-predpisy/SK/ZZ/2012/442/20200701

22. Ministry of Finance of the Slovak Republic (2019). Guideline of the Ministry of Finance of the Slovak Republic no. MF / 014283 / 2018-724. Retrieved from: https://www.mfsr.sk/sk/dane-cla-uctovnictvo/priame-dane/dane-z-prijmu/transferoveocenovanie/novinky-oblasti-transferoveho-ocenovania/

23. Blazek, R., Durana, P., Valaskova, K. (2020). Creative accounting as an apparatus for reporting profits in agribusiness. Journal of Risk and Financial Management, 13(11), 261.

24. Klassen, K. J., Lisowsky, P., Mescall, D. (2017). Transfer Pricing: Strategies, Practices, and Tax Minimization. Contemporary Accounting Research, 34(1), 455 493. 